\title{
Temperature dependent structural, morphological, FTIR, optical, magnetic properties of NiMgZn ferrites
}

\author{
T. Vidya Sagar*, T. Subba Rao, N. Raghuram \\ Dept. of Physics, Sri Krishnadevaraya University, Anantapuramu-515003, A.P, India \\ tvidyasagar83@gmail.com
}

DOI 10.17586/2220-8054-2020-11-4-434-443

\begin{abstract}
$\mathrm{NiMgZn}$ ferrites with chemical composition $\mathrm{Ni}_{0.2} \mathrm{Mg}_{0.3} \mathrm{Zn}_{0.5} \mathrm{Fe}_{2} \mathrm{O}_{4}$ nanomaterials were synthesized using the sol-gel technique. The various properties of the samples prepared at three different calcination temperatures $(T)$ of 400,450 and $500{ }^{\circ} \mathrm{C} / 5 \mathrm{hr}$ were studied. The $\mathrm{X}$-ray diffraction study confirmed the single-phase cubic spinel structure (JCPDS 08-0234) for $400 \& 500{ }^{\circ} \mathrm{C}$ calcined samples and with Fe $\mathrm{O}_{3}$ as an impurity phase for $450{ }^{\circ} \mathrm{C}$ calcined sample with lattice parameter values 8.296 to $8.376 \AA$. The surface morphology and EDX spectra observed with field emission scanning electron microscope (FESEM) images confirmed the nano-sized irregular shaped grain development at low calcination temperatures. The force constants are determined using FTIR spectroscopy confirmed the M-O bonds present in ferrites. Optical band gap properties studied and found that NiMgZn ferrites have band gaps in semiconducting region from 1.68 to $1.75 \mathrm{eV}$. The susceptibility-temperature $(\chi-T)$ dependence is studied using a Bartington MS2B Dual Frequency instrument in heating and cooling modes and magnetic transition temperature (Tc) were determined. The highest magnetic susceptibility of 1293 is observed for $500{ }^{\circ} \mathrm{C}$ calcined material. By using VSM, the M-H loop, magnetic properties are studied, which showed that this material is ferrimagnetic. Also, the magnetic moments and saturation magnetizations ( $M s)$ are calculated. The maximum saturation magnetization $97.20 \mathrm{emu} / \mathrm{g}$ is observed for $400{ }^{\circ} \mathrm{C}$ calcined sample.
\end{abstract}

Keywords: ferrites, sol-gel, X-ray diffraction, magnetic properties.

Received: 28 March 2020

Revised: 30 April 2020

Final revision: 13 May 2020

\section{Introduction}

Spinel ferrites having a variety of applications in the fields of data storage, transformer cores, anti-bacterial activities, soft magnetic applications, biomedical, sensors, high frequency components, LTCC devices, super capacitors, microwave absorption, photo catalytic activity and drug delivery etc. [1-4].

The properties of spinel ferrites $\left(\mathrm{A}^{+2} \mathrm{Fe}_{2}^{+3} \mathrm{O}_{4} \mathrm{~A}\right.$ : Cations such as $\mathrm{Ni}^{+2}, \mathrm{Co}^{+2}, \mathrm{Zn}^{+2}, \mathrm{Mn}^{+2}, \mathrm{Cr}^{+2}, \mathrm{Mg}^{+2}$, etc. depend on various parameters, such as synthesis, particle size, morphology and cationic distributions at the tetrahedral and octahedral positions in the unit cell etc. Many studies have been performed by introducing non-magnetic ions such as $\mathrm{Mn}, \mathrm{Zn}, \mathrm{Cu}, \mathrm{Sn}, \mathrm{Mg}$, etc. to observe the changes in the magnetic and other properties of spinel ferrites using different synthesis methods. The magnetic parameters vary due to the cationic transition from A, B sites. This can be done by substitution of different $\mathrm{Zn}^{+2}, \mathrm{Mg}^{+2}, \mathrm{Mn}^{+2}, \mathrm{Cu}^{+2}$, etc. At the nanoparticle scale the properties of spinel ferrites are significantly different compared to that of bulk materials because of their size and stoichiometry. Nanoscaled ferrites are used in many applications like sensor applications, bio-medical applications, data storage [5-8]. Also, nano ferrites are used for microwave absorption and EMI shielding properties [9]. The magnetic properties may be enhanced significantly at the nano scale [14].

MN Akhtar prepared NiMgZn ferrites using sol-gel method at $650{ }^{\circ} \mathrm{C}$ for 4 hours and showed that they are useful for microwave absorption and High Frequency applications [1].

S. Ramesh et al. prepared NiZnCo and NiZnMn ferrites using sol-gel auto combustion method at $1200{ }^{\circ} \mathrm{C}$ have showed that these ferrites can be used in the transformer cores and inductors upto several $\mathrm{MHz}$ [5].

Rohit Sharma et al. prepared Ni doped $\mathrm{Mg}-\mathrm{Zn}$ spinel ferrites using co precipitation method at $900{ }^{\circ} \mathrm{C}$ and they can be used in high density information storage, magnetic recording and memory devices [8].

In our present work, we synthesized nano NiMgZn ferrites via sol-gel method, as it has many advantages, such as uniform reaction rates, compositional control, low cost synthesis, etc. The majority of research mentioned above has synthetic temperatures above $500{ }^{\circ} \mathrm{C}$. Hence, we decided to study the properties of NiMgZn ferrites calcined at three temperatures 400,450 and $500{ }^{\circ} \mathrm{C}$ for $5 \mathrm{hr}$. The synthesized samples were characterized by XRD, FESEM, EDX, FTIR, UV and VSM. 


\section{Experimental procedure}

$\mathrm{Fe}\left(\mathrm{NO}_{3}\right)_{3} \cdot 9 \mathrm{H}_{2} \mathrm{O}, \mathrm{Ni}\left(\mathrm{NO}_{3}\right)_{2} \cdot 6 \mathrm{H}_{2} \mathrm{O}, \mathrm{Zn}\left(\mathrm{NO}_{3}\right)_{2} \cdot 6 \mathrm{H}_{2} \mathrm{O}, \mathrm{Mg}\left(\mathrm{NO}_{3}\right)_{3} \cdot 6 \mathrm{H}_{2} \mathrm{O}$, and $\mathrm{C}_{6} \mathrm{H}_{8} \mathrm{O}_{7}$ (citric acid, anhydrous), $\mathrm{NH}_{3}(25 \%)$ solution were used as precursor materials. The stoichiometric weighed amounts of these metal nitrates were completely dissolved in $50 \mathrm{ml}$ of distilled water. This solution was then added to $50 \mathrm{ml}$ of citric acid solution. The molar ratio of these nitrates and citric acid is fixed as 1:1. Then the solution is stirred for 30 minutes to obtain a clear solution using a magnetic stirrer with hot plate. After this ammonia solution was added drop-wise using a burette to achieve a $\mathrm{pH}$ value of 7 for the solution with stirring it simultaneously. The solution is continuously stirred with a rotation speed $470 \mathrm{rpm}$. Condensation reaction occurs between the adjacent metal nitrates and the molecules of citrates, yielding a polymer network in colloidal dimensions known as sol. The stirring is continued for $1 \mathrm{hr}$. Then,the solution was slowly evaporated by intensive stirring and heating for $6 \mathrm{hr}$ at $80{ }^{\circ} \mathrm{C}$ and was kept at that temperature until the solution turned into a gel. The gel was then calcined at $400,450,500{ }^{\circ} \mathrm{C}$ for $5 \mathrm{hr}$ in a furnace. The resulting powder was finely grounded using an agate mortar. Then this powders was characterized using the X-ray diffractometer (XRD, Bruker, CuK $\alpha \lambda=0.15406 \mathrm{~nm}$ ), field-emission scanning electron microscope (FE-SEM, Ultra 55, Carl Zeiss), magnetic susceptibility measurement ( $\chi-T$ curves) with Bartington MS2WFP furnace system (40 $700{ }^{\circ} \mathrm{C}$ ), FTIR spectrometer and UV-Visible Spectrometer for structural, morphological, magnetic susceptibility and optical properties.

\section{Results and discussion}

\subsection{X-Ray diffraction studies}

The two-theta versus counts plots of NiMgZn ferrites were as shown in Fig. 1 for 400,450 , and $500{ }^{\circ} \mathrm{C}$. These X-ray diffraction peaks (111), (220), (311), (222), (400), (422),(511), (440), (620), (533) revealed the cubic spinel structure (JCPDS 08-0234). The average crystallite size $(D)$ was determined using the Scherrer formula: $0.9 \lambda / \beta \cos \theta$, for major peaks and for (311) planes, where $\lambda$ is the wavelength $(0.15406 \mathrm{~nm})$ of $\mathrm{CuK} \alpha$ radiation, $\beta$ is the full width half maxima (FWHM) and $\theta$ is the diffraction angle [13]. The material calcined at $450{ }^{\circ} \mathrm{C}$ showed the presence of $\mathrm{Fe}_{2} \mathrm{O}_{3}[3,14,15]$; this may be due to the incomplete decomposition or non-reacted pre cursors at that temperature as well as lattice distortion. The results of XRD data were displayed in Table 1.

TABLE 1. Structural Parameters of NiMgZn Ferrites calcined at different temperatures

\begin{tabular}{|c|c|c|c|c|c|c|c|c|c|c|}
\hline $\begin{array}{c}\text { S. } \\
\text { No }\end{array}$ & $\begin{array}{c}\text { Calcination } \\
\text { Temperature } \\
\left({ }^{\circ} \mathrm{C}\right)\end{array}$ & $\begin{array}{c}a(\AA) \\
\pm 0.001\end{array}$ & $\begin{array}{c}V(\AA)^{3} \\
\pm 0.001\end{array}$ & $\begin{array}{c}\text { Avg } \\
\mathrm{nm} \\
\pm 1.0\end{array}$ & $\begin{array}{c}2 \theta \\
\text { For } \\
\text { planes }\end{array}$ & $\begin{array}{c}D \mathrm{~nm} \\
\text { from } \\
\text { plane } \\
\mathrm{nm} \\
\pm 1.0\end{array}$ & $\begin{array}{c}\rho_{x} \\
\mathrm{~g} / \mathrm{cm}^{3} \\
\pm 0.0001\end{array}$ & $\begin{array}{c}\rho_{b} \\
\mathrm{~g} / \mathrm{cm}^{3} \\
\pm 0.001\end{array}$ & $\begin{array}{c}\text { Porosity } \\
P(\%) \\
\pm 0.001\end{array}$ & $\begin{array}{c}\text { Specific } \\
\text { Surface } \\
\text { Area } \\
S\left(\mathrm{~m}^{2} / \mathrm{g}\right) \\
(6000 / \\
\left.\rho_{b} \cdot D_{311}\right)\end{array}$ \\
\hline \hline 1 & 400 & 8.374 & 587.217 & 46.7 & 35.52 & 38.1 & 5.1429 & 4.314 & 16.117 & 36.50 \\
\hline 2 & 450 & 8.296 & 570.960 & 15.5 & 35.88 & 12.4 & 5.2893 & 4.463 & 15.622 & 108.50 \\
\hline 3 & 500 & 8.376 & 587.638 & 54 & 35.52 & 47 & 5.1392 & 4.521 & 12.029 & 28.24 \\
\hline
\end{tabular}

It was found that the crystalline size was about $15.5 \mathrm{~nm}$ for the $450{ }^{\circ} \mathrm{C}$ calcined material; this was attributed due to the high FWHM values observed and other two samples are 46.7 and $54 \mathrm{~nm}$. The $450{ }^{\circ} \mathrm{C}$ calcined sample had small average crystalline size and comparable with the crystallite size observed with (311) plane. This may be due to the high micro strain produced either in synthesis processes or calcination temperature. The lattice parameter $a=b=c$ is 8.374, 8.296 and $8.376 \AA$ are calculated from (311) plane using Bragg's equation $a=\frac{\sqrt{11} \cdot 1.5406}{\sin \theta} \AA$ show the densification of unit cell at $450{ }^{\circ} \mathrm{C}$ which was observed in X-Ray density. The interplanar spacing for $d_{311}$ is 2.769 , 2.750 and $2.737 \mathrm{~nm}$ respectively, calculated from the formula $d_{311}=\frac{a}{\sqrt{11}}$. The X-Ray density is determined from $\rho_{x}=\frac{n \cdot M W}{N_{a} \cdot a^{3}}$, where $M W$ is the molecular weight of the sample equal to $227.36 \mathrm{~g} / \mathrm{mole}, N_{a}$ is the Avogadro's number $-6.023 \times 10^{23}$ atoms/mole, $a$ is the lattice parameter and $n=8$, the effective number of atoms for a facecentered cubic structure. The maximum X-Ray density was found to be $5.2893 \mathrm{~g} / \mathrm{cm}^{3}$ is for $450{ }^{\circ} \mathrm{C}$ calcinated sample. The bulk densities are measured by preparing pellets which is calculated from $\rho_{b}=\frac{m}{3.14 \cdot r^{2} \cdot t}$, where $m$ is the mass, 


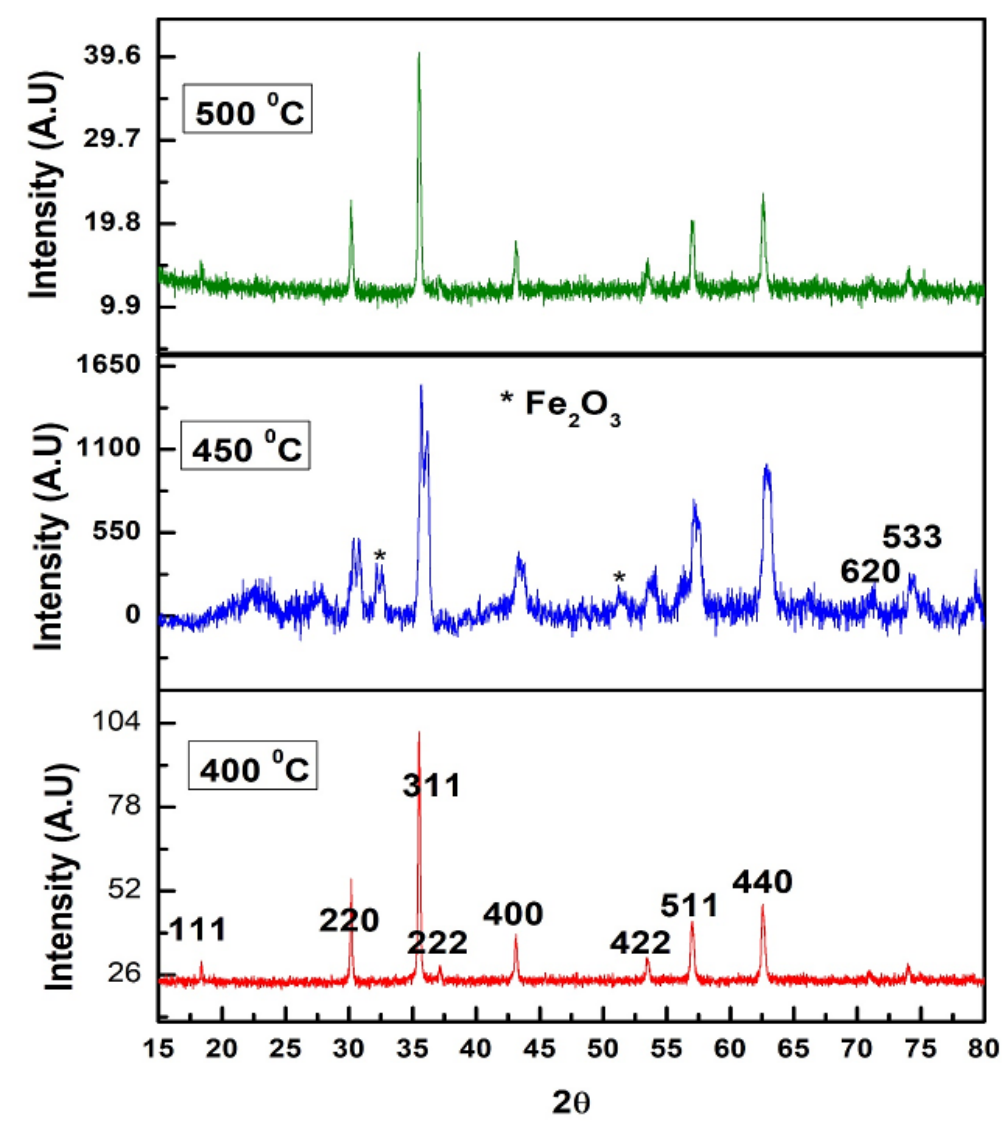

FIG. 1. X-Ray diffraction pattern of NiMgZn Ferrite calcined at $400,450,500{ }^{\circ} \mathrm{C}$

$r$ is the radius and $t$ is the thickness of the pellets prepared. The bulk density shows increasing trend for increase in calcination temperature due to expanding of grains over the surface. The porosity $(P)$ can be calculated using the equation $P \%=\left[1-\frac{\rho_{b}}{\rho_{x}}\right] \times 100$ was found to be decreased with increasing calcination temperature, because of improvement in the crystallinity of the samples [12,13]. The specific surface area is high for $450{ }^{\circ} \mathrm{C}$ calcinated sample about $108.50 \mathrm{~m}^{2} / \mathrm{g}$. Even though this surface area is high there is no significant influence on the other properties is observed. This may be due to partial ferrite phase formation at $450{ }^{\circ} \mathrm{C}$.

\subsection{Surface morphology study}

The surface morphology and EDX images of the ferrite samples of the pellets prepared were shown in the Fig. 2(a,b and c) respectively. The morphology observed is similar for three calcination temperatures, whereas the $400{ }^{\circ} \mathrm{C}$ calcined sample showed irregular grains, the $450{ }^{\circ} \mathrm{C}$ calcined sample showed a uniform grain structure. The $500{ }^{\circ} \mathrm{C}$ calcined sample showed densified grains agglomerated at some places. The crystallinity improved well with an increase in temperature. For all samples, the particle size is in the range of $\mathrm{nm}$.

The EDX study is used to perform to know the stoichiometric \& elemental details of the composition. The EDX data of the samples prepared is listed in the Table 2. The EDX data provides the elemental composition of $\mathrm{Ni}, \mathrm{Mg}$, $\mathrm{Zn}, \mathrm{Fe}$ and $\mathrm{O}$. All the samples have the nearest stoichiometry to the $\mathrm{Ni}_{0.2} \mathrm{Mg}_{0.3} \mathrm{Zn}_{0.5} \mathrm{Fe}_{2} \mathrm{O}_{4}$ composition prepared and it is represented in Table 2.

\subsection{FTIR spectroscopy}

Figure 3 shows the FTIR spectra recorded in the $200-1000 \mathrm{~cm}^{-1}$ range for NiMgZn ferrites calcined at different temperatures. The absorption bands and the tetrahedral, octahedra force constants were determined from the formula $K_{t}=4 \pi^{2} c^{2} \vartheta_{t} \mu_{m}$ and $K_{o}=4 \pi^{2} c^{2} \vartheta_{o} \mu_{m}$, where $c=2.99 \times 10^{10} \mathrm{~cm} / \mathrm{s}$ and $\mu_{m}$ is the reduced mass of Fe $\mathrm{F}^{+3}$ and $\mathrm{O}^{-2}$ equal to $2.60 \times 10^{-23} \mathrm{~g}$ [1]. The absorption bands were observed in the 430 to $564 \mathrm{~cm}^{-1}$ range. The observed absorption bands confirmed the formation of spinel ferrites. The force constants determined for three different calcination temperatures were shown in the Table 3. The table shows as the temperature increased, the cations preferentially 
(a)
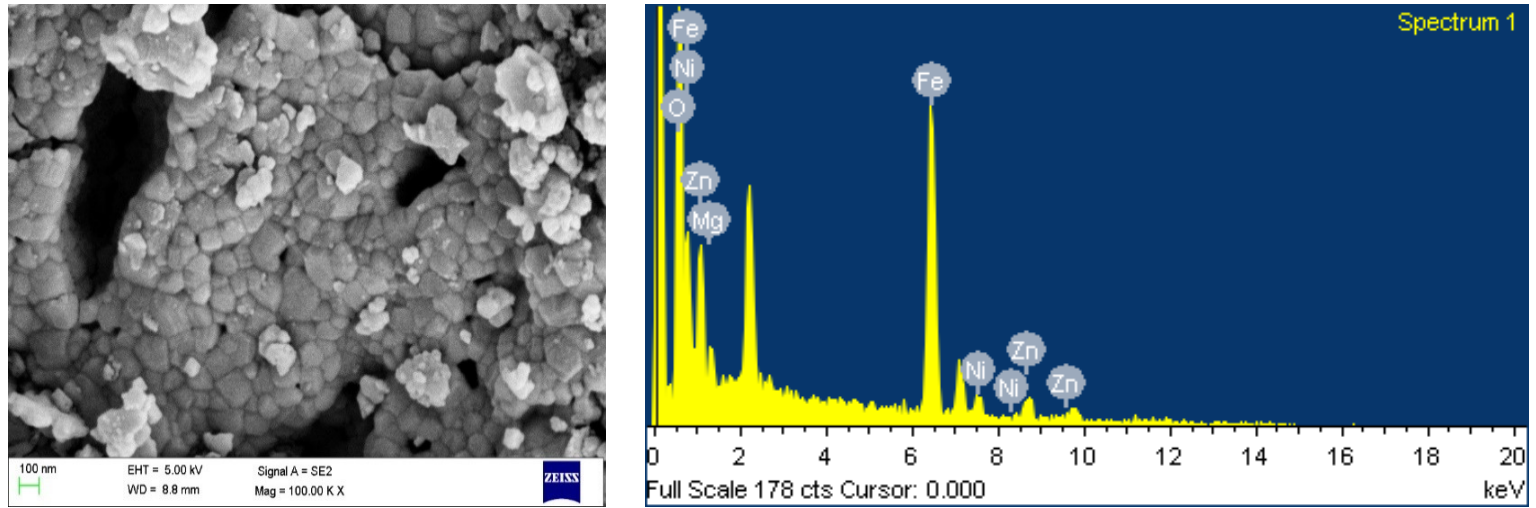

(b)
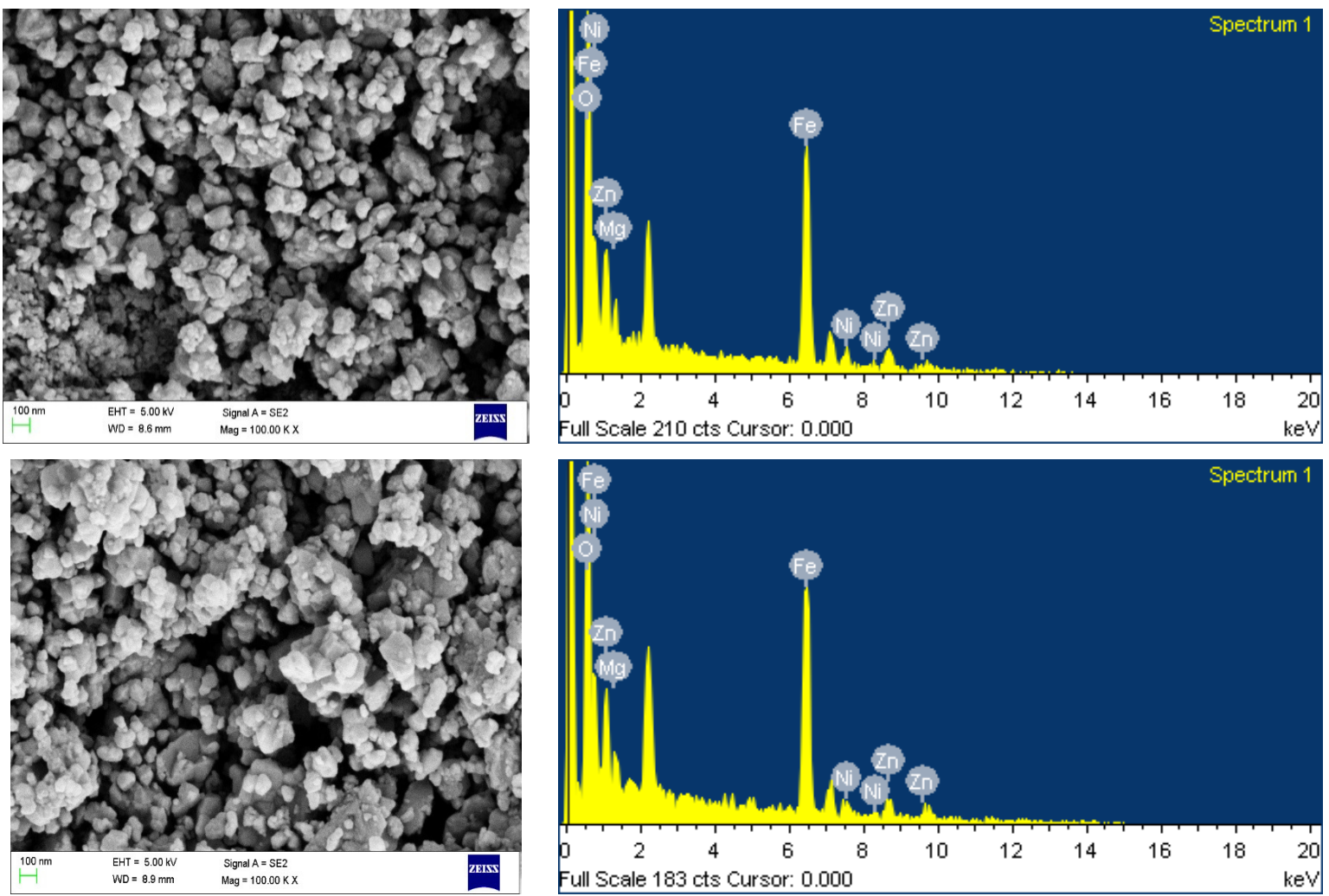

FIG. 2. FESEM Images of NiMgZn Ferrites calcined at 400 (a), 450 (b), 500 (c) ${ }^{\circ} \mathrm{C}$ and EDX Data TABLE 2. EDS Data of NiMgZn Ferrites

\begin{tabular}{|c|c|c|c|c|c|c|c|c|c|}
\hline $\begin{array}{c}\text { Element } \\
\text { and } \\
\left(\begin{array}{c}\text { compo- } \\
\text { sition) }\end{array}\right.\end{array}$ & $\begin{array}{c}\text { Weight } \\
\% \\
100 \%\end{array}$ & $\begin{array}{c}\text { Atomic } \\
\%\end{array}$ & $\begin{array}{c}\text { Calculated } \\
\text { compo- } \\
\text { sition } \\
\pm \mathbf{0 . 0 0 1}\end{array}$ & $\begin{array}{c}\text { Weight } \\
\% \\
100 \%\end{array}$ & $\begin{array}{c}\text { Atomic } \\
\%\end{array}$ & $\begin{array}{c}\text { Calculated } \\
\text { compo- } \\
\text { sition } \\
\pm \mathbf{0 . 0 0 1}\end{array}$ & $\begin{array}{c}\text { Weight } \\
\% \\
100 \%\end{array}$ & $\begin{array}{c}\text { Atomic } \\
\%\end{array}$ & $\begin{array}{c}\text { Calculated } \\
\text { compo- } \\
\text { sition } \\
\pm \mathbf{0 . 0 0 1}\end{array}$ \\
\hline \hline $\mathbf{N i}(\mathbf{0 . 2})$ & 6.12 & 3.50 & 0.256 & 5.21 & 3.08 & 0.237 & 6.59 & 3.90 & 0.299 \\
\hline $\mathbf{M g}(\mathbf{0 . 3})$ & 2.84 & 3.93 & 0.287 & 2.83 & 4.04 & 0.310 & 2.42 & 3.46 & 0.265 \\
\hline $\mathbf{Z n}(\mathbf{0 . 5})$ & 14.33 & 7.37 & 0.539 & 15.29 & 8.11 & 0.623 & 13.21 & 7.02 & 0.538 \\
\hline $\mathbf{F e}(\mathbf{2})$ & 50.66 & 30.48 & 2.228 & 52.65 & 32.70 & 2.51 & 53.76 & 33.45 & 2.564 \\
\hline $\mathbf{O}(\mathbf{4})$ & 26.05 & 54.71 & 4 & 24.02 & 52.07 & 4 & 24.02 & 52.17 & 4 \\
\hline
\end{tabular}


occupied the octahedral sites, hence increase in the force constants at octahedra sites was observed. Some other absorption bands are due to $\mathrm{O}-\mathrm{H}, \mathrm{C}-\mathrm{H}$ and $\mathrm{COO}$ groups which are not shown in the figure. The Debye temperature is used to study the vibrations of lattice. The Debye temperatures were calculated from $\theta_{D}=\frac{h c \vartheta_{\text {average }}}{k_{B}}[3,16]$ and depicted in Table 3. The Debye temperatures were found increase with an increase in the calcination temperature. This is attributed due to the increase in the wave number related to $\mathrm{Me}-\mathrm{O}$ at tetragonal site. The increasing trend of Debye temperatures indicates the reduction of the lattice vibrations due to an increase in the calcination temperature linked with improved crystallinity.

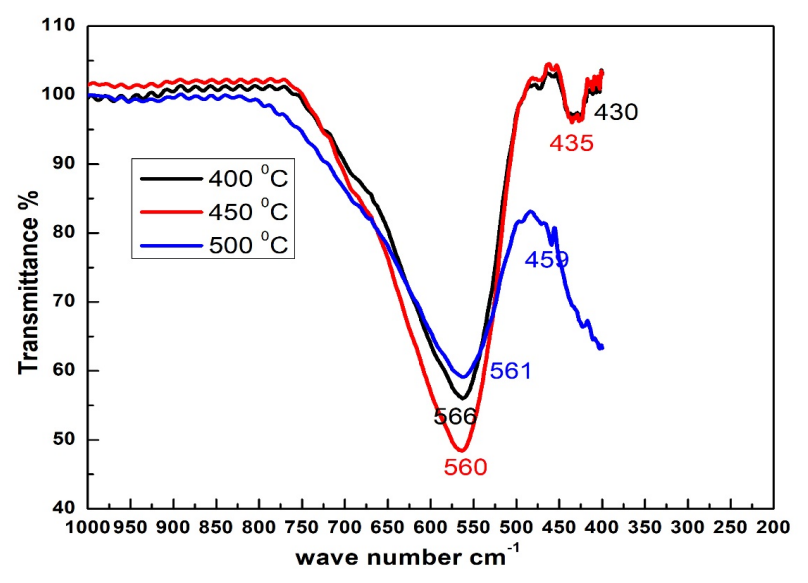

FIG. 3. FTIR spectra of NiMgZn ferrite indicating prominent M-O bonds

TABLE 3. The force constants obtained from FTIR spectroscopy \& optical band gap from UVVisible spectroscopy at tetrahedral and octahedral sites for NiMgZn ferrites

\begin{tabular}{|c|c|c|c|c|c|c|c|}
\hline $\begin{array}{c}\text { S. } \\
\text { No }\end{array}$ & $\begin{array}{c}\text { Calcination } \\
\text { Temperature } \\
{ }^{\circ} \mathrm{C}\end{array}$ & $\begin{array}{c}\nu_{t} \\
\mathrm{~cm}^{-1}\end{array}$ & $\begin{array}{c}\nu_{o} \\
\mathrm{~cm}^{-1}\end{array}$ & $\begin{array}{c}K_{t} \times 10^{5} \\
\text { Dyne/cm }\end{array}$ & $\begin{array}{c}K_{o} \times 10^{5} \\
\text { Dyne/cm }\end{array}$ & $\begin{array}{c}\text { Debye } \\
\text { Temperatures } \\
\theta_{D}(\mathrm{~K})\end{array}$ & $E_{g}(\mathrm{eV})$ \\
\hline \hline 1 & 400 & 564 & 430 & 2.918 & 1.695 & 713.195 & 1.68 \\
\hline 2 & 450 & 566 & 435 & 2.937 & 1.735 & 718.217 & 1.73 \\
\hline 3 & 500 & 560 & 461 & 2.877 & 1.948 & 732.567 & 1.75 \\
\hline
\end{tabular}

\subsection{UV-Visible spectroscopy}

UV-Visible spectroscopy was used to determine the optical bad gaps of the materials. The diffuse reflectance spectra (DRS) were recorded using UV-Visible spectrophotometer in the $240-2600 \mathrm{~nm}$ range for the NiMgZn ferrites. The Kubelka-Munk function (function of reflectance) was calculated using the relation $F(R)=(1-R)^{2} / 2 R$, where $R$ can reflect the reflectance. It is a well-known fact that the $F(R)$ is directly proportional to the absorption coefficient $(\alpha)$. Hence, in place of $\alpha$, the numerical value of $F(R)$ would be considered. By using the equation $(\alpha h v)^{n}=K\left(h v-E_{g}\right)$, where $h v$ indicated the photon's energy, $n$ reflected exponent and the rest of the symbols have their general meaning. Herein, $n$ can provide the information related to the kind of transition between valency $\left(V_{B}\right)$ and conduction bands $\left(C_{B}\right)$. That is, for direct transition of charges between $V_{B}$ and $C_{B}, n$ value is equal to 2 while for indirect transition $n$ is to be 0.5 . As we are considered only direct transition of charges from the two bands so that $n=2$ was taken for determining the $E_{g}$ values [17]. The plot of $(\alpha h v)^{2}$ Vs $h v$ graphs of NiMgZn ferrites calcined at three calcination temperatures $(T)$ values shown in Fig. 4(a,b,c). After plotting the graphs, the linear potion of each plot was extrapolated towards the direction of $x$-axis. The photon energy position intersected portion of the plot was the optical band gap of the sample $E_{g}$. From the last column of Table 3, it was observed that the $E_{g}$ values of all compositions were increased with an increase in the calcination temperature. The NiMgZn ferrites compositions calcined at $400-500{ }^{\circ} \mathrm{C}$ showed the increasing trend of $E_{g}$ value from 1.68 to $1.75 \mathrm{eV}$. This kind of behavior can be commonly explained by the localized and delocalized electrons. The localized electrons increased with the increasing calcination temperature, such that the band gap increased and it indicated a structure with fewer oxygen defects. 
(a)
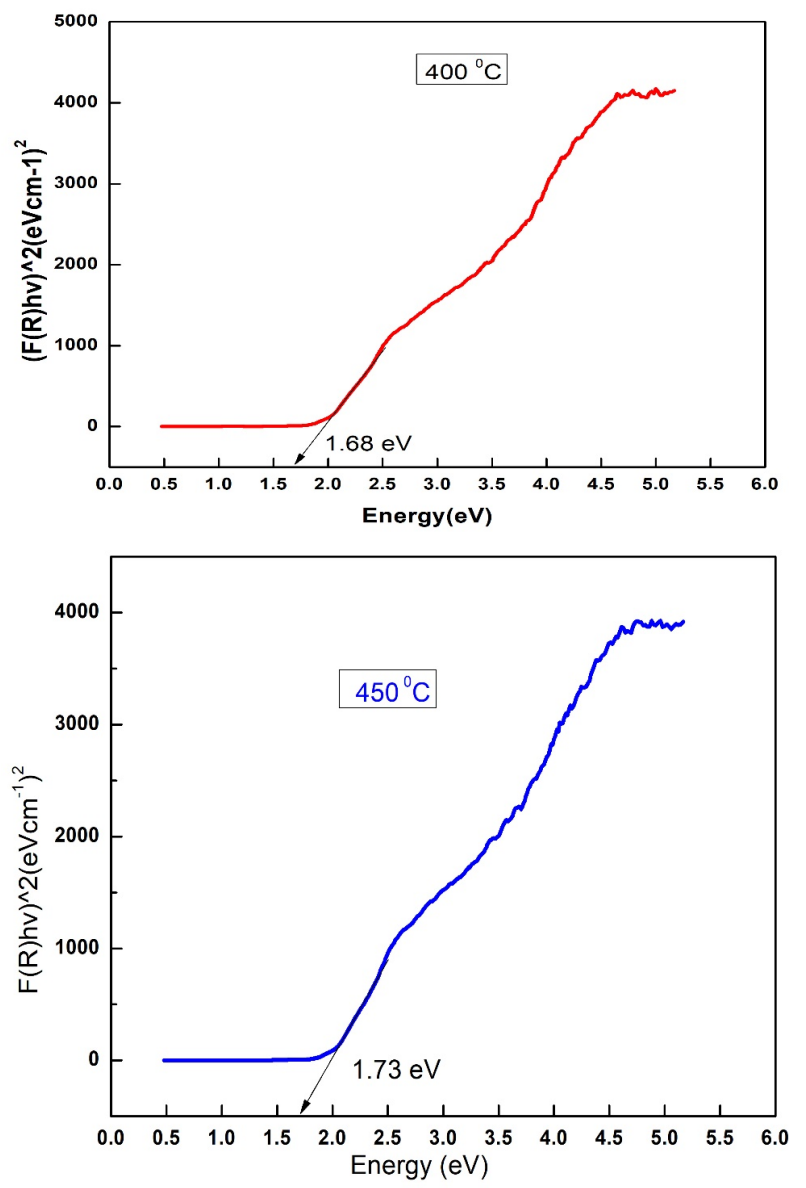

(b)

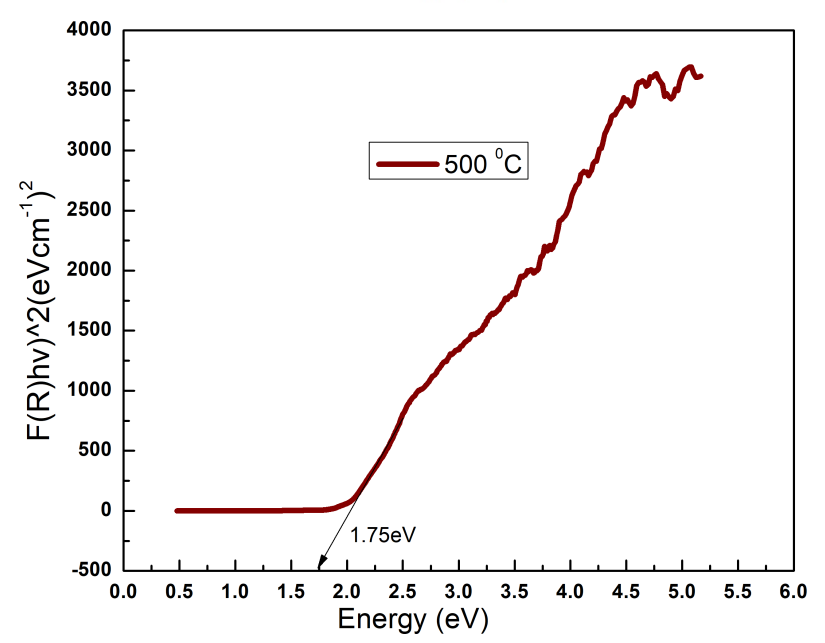

FIG. 4. Optical Band gap of Nano NiMgZn ferrites calcined at 400 (a), 450 (b) and 500 (c) ${ }^{\circ} \mathrm{C}$ 


\subsection{Susceptibility of NiMgZn ferrites}

The susceptibilities were recorded in heating mode and cooling mode using a Bartington MS2B Dual Frequency instrument from $40-700{ }^{\circ} \mathrm{C}$ in order to study the magnetic temperature and shown in Fig. 5. With this, we can estimate the ferrimagnetic to paramagnetic behavior of the samples. Both the heating and cooling mode curves showed the same trend. The samples calcined at 400 and $500{ }^{\circ} \mathrm{C}$ are exhibiting perfect ferromagnetic to paramagnetic behavior, while the sample calcined at $450{ }^{\circ} \mathrm{C}$ showed deviation from ferromagnetic behavior; this may due to the significant formation of $\mathrm{Fe}_{2} \mathrm{O}_{3}$ at that temperature, which was observed in XRD. Since the magnetic susceptibility depends on the type of dopant and microstructure, the deviation of nature is due to the formation of $\mathrm{Fe}_{2} \mathrm{O}_{3}[3,15,18]$. The susceptibility recorded at $40{ }^{\circ} \mathrm{C}$ for all samples increased with calcination temperature. The magnetic transition temperature $\left(T_{c}\right)$ increased from 438 to $446{ }^{\circ} \mathrm{C}$ and then decreased to $418{ }^{\circ} \mathrm{C}$.

(a)
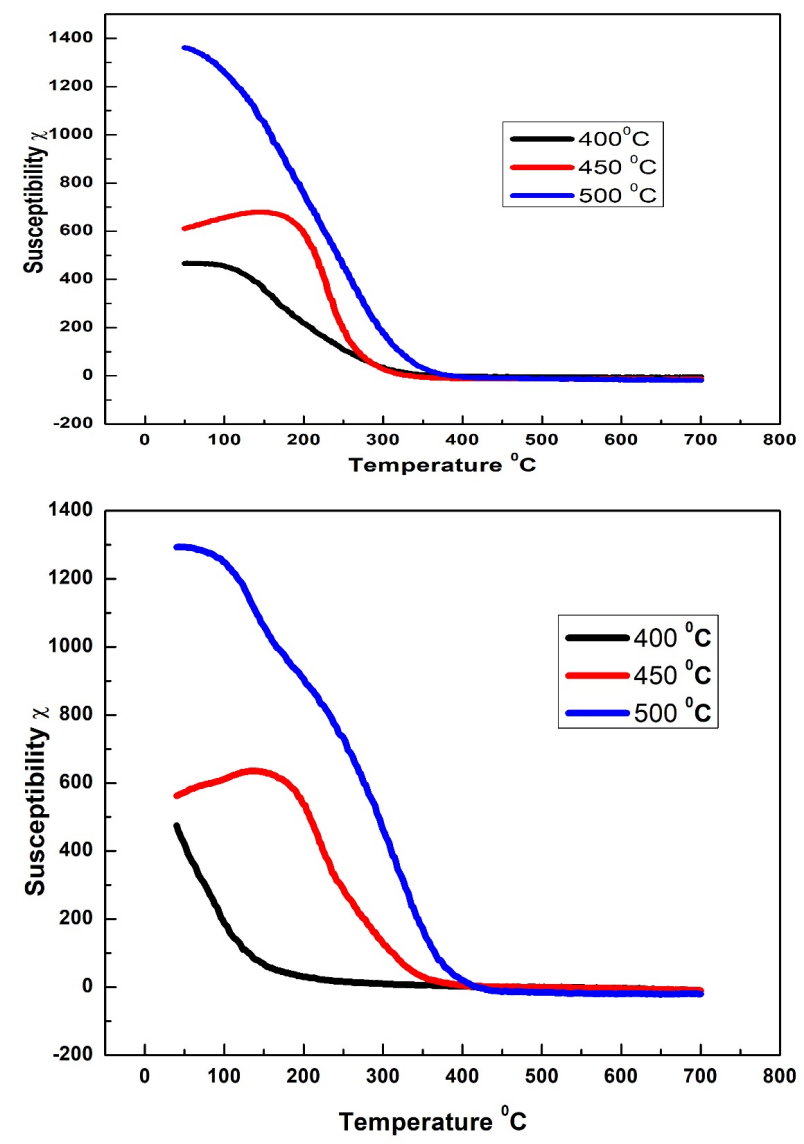

FIG. 5. Susceptibility and temperature graph in cooling (a) and heating (b) mode

\subsection{M-H loop analysis}

Figure 6 represents the room temperature hysteresis behavior of the NiMgZn ferrites calcined at different temperatures over the field range from -15 to $+15 \mathrm{k}$ Oe at room temperature. The various magnetic parameters, such as remanent magnetization $(M r)$, saturation magnetization $(M s), M r / M s$, Magnetic moment $\left(n_{B}\right)$ in Bohr magnetons $\left(\mu_{B}\right)$, Coercive field $(H c)$, Anisotropy constant $(K a c)$ are shown in the Table 4 . The remanent magnetization decreased with calcination temperature; also, the saturation magnetization decreased from 97.20 to $90.20 \mathrm{emu} / \mathrm{g}$. The coercivity decreased with an increase in the calcination temperature. This can be attributed to a decrease in the ferrimagnetic nature. The decreased coercivity of the samples can be explained on the basis of magnetic crystallineanisotropy, which depends on various parameters such as cationic distribution, specific surface area, grain size, density, synthesis method, etc [8]. Magnetic moments also decrease from 3.95 to 3.67. This can be explained as follows. As the temperature increases the concentration of Fe ions on B site will be decreased so that, the magnetic moment at B site will be decreased and magnetic moment at A site be increases due to increase in the concentration of Fe ions at A site as a result the net magnetic moment will be decreased according to Neel's model [20,22]. However, with the 
formation of iron oxide for the $450{ }^{\circ} \mathrm{C}$ calcined sample, more $\mathrm{Fe}^{+3}$ ions occupy the A sites. By comparing the samples calcined at 400 and $500{ }^{\circ} \mathrm{C}$, we can conclude that as the calcination temperature increased $\mathrm{Fe}$ ions will occupied more A sites compared to B sites, and hence, the magnetic moment decreased. The squareness values all are less than 0.5 indicates the contribution of uniaxial anisotropy of the synthesized nano ferrites. Due to small values of coercivity and remanence magnetization, this material can be used in high frequency electronic instruments. Also, the increase in the calcination temperature reduced the canting effect of $\mathrm{Zn}$ in the ferrites [14,21].

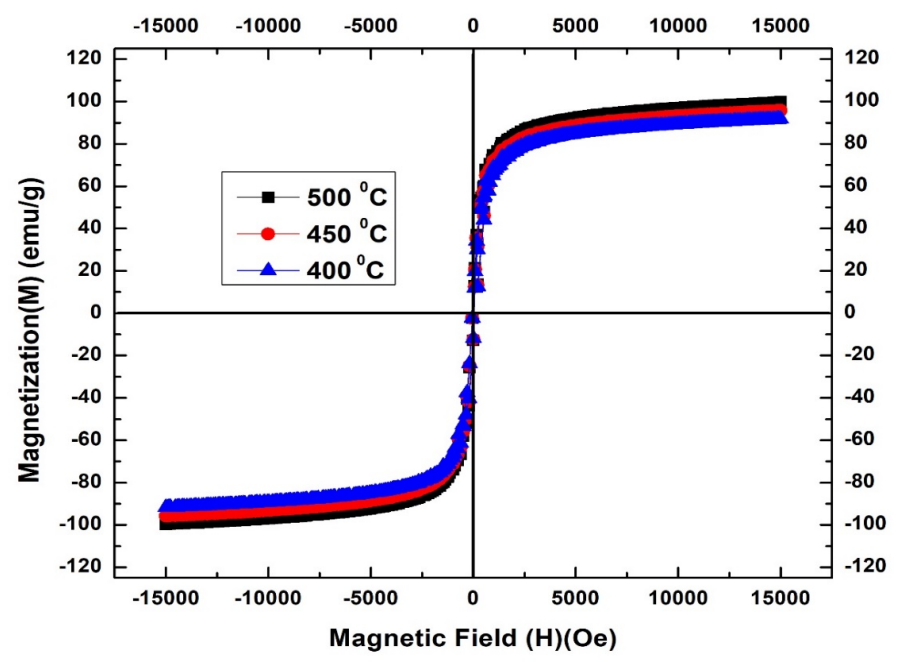

FIG. 6. M-H curves of NiMgZn ferrites

TABLE 4. The magnetic parameters of the nano NiMgZn ferrites

\begin{tabular}{|c|c|c|c|c|c|c|c|c|c|}
\hline $\begin{array}{c}\text { S. } \\
\text { No }\end{array}$ & $\begin{array}{c}\text { Calcination } \\
\text { Temperature } \\
{ }^{\circ} \mathrm{C}\end{array}$ & $\begin{array}{c}M r \\
(\mathrm{emu} / \mathrm{g})\end{array}$ & $\begin{array}{c}M s \\
(\mathrm{emu} / \mathrm{g})\end{array}$ & $M r / M s$ & $\begin{array}{c}n_{B}(\mathrm{emu} / \mathrm{g})= \\
\frac{M W \cdot M s}{5585}\end{array}$ & $\begin{array}{c}H c \\
(\mathrm{Oe})\end{array}$ & $\begin{array}{c}\text { Anisotropy } \\
\text { constant } \\
(\mathrm{erg} / \mathrm{cc}) \\
K_{a c}=\frac{H_{c} M s}{0.96}\end{array}$ & $\begin{array}{c}T m \\
\left({ }^{\circ} \mathrm{C}\right) \\
\text { heating } \\
\text { mode }\end{array}$ & $\begin{array}{c}\chi \\
\text { at } \\
40{ }^{\circ} \mathrm{C}\end{array}$ \\
\hline \hline 1 & 400 & 13.80 & 97.20 & 0.1419 & 3.95 & 48.36 & 4896.45 & 438 & 453 \\
\hline 2 & 450 & 12.62 & 95.76 & 0.1318 & 3.89 & 47.25 & 4713.19 & 446 & 663 \\
\hline 3 & 500 & 5.01 & 90.20 & 0.0555 & 3.67 & 42.65 & 4007.32 & 418 & 1293 \\
\hline
\end{tabular}

A comparative study of present work with the related compositions is represented in Table 5.

\section{Conclusions}

NiMgZn ferrites were synthesized by the sol-gel method. This ferrites had a spinel cubic structure with lattice parameter ranges from 8.296 to $8.376 \AA$ and crystalline size about 15.47 to $54.02 \mathrm{~nm}$. The presence of iron oxide major phase is observed for the sample calcinated at $450{ }^{\circ} \mathrm{C}$. The FESEM-EDX images confirms the uniform grains and desired elements present in all samples prepared. The FTIR spectrum shows the prominent absorption bands in the $430-564 \mathrm{~cm}^{-1}$ range, confirming the spinel ferrites were formed. The optical band gaps are found to be 1.68 to $1.7 \mathrm{eV}$, showing the semiconducting nature of the ferrites. The susceptibility and temperature study confirm the ferromagnetic nature decreased as the temperature increased. The ferromagnetic susceptibilities at $40{ }^{\circ} \mathrm{C}$ varied from 453 to 1293 . The saturation magnetization and coercivity decreased with increase of calcination temperatures as a greater number of $\mathrm{Fe}^{+3}$ ions occupy the tetrahedral sites. The samples prepared at 400 and $450{ }^{\circ} \mathrm{C}$ are ferrimagnetic in nature, whereas the sample prepared at $500{ }^{\circ} \mathrm{C}$ displays a soft magnetic nature. These ferrite materials have potential applications in photocatalytic activity, drug delivery and other ferrimagnetic applications. 
TABLE 5. Comparative data of NiMgZn ferrites prepared by various researchers

\begin{tabular}{|c|c|c|c|c|c|c|c|c|c|c|}
\hline $\begin{array}{l}\text { S. } \\
\text { No }\end{array}$ & $\begin{array}{l}a \\
\AA\end{array}$ & $\begin{array}{c}D \\
(\mathrm{~nm})\end{array}$ & $\begin{array}{c}M s \\
(\mathrm{emu} / \mathrm{g})\end{array}$ & $\begin{array}{c}H c \\
(\mathrm{Oe})\end{array}$ & $\mu_{B}$ & $\begin{array}{c}S \\
\left(\mathrm{~m}^{2} / \mathrm{g}\right)\end{array}$ & $\begin{array}{c}K_{t} \\
\times 10^{5} \\
\text { dyne/ } \\
\mathrm{cm}^{2} \\
\end{array}$ & $\begin{array}{c}K_{0} \\
\times 10^{5} \\
\text { dyne/ } \\
\mathrm{cm}^{2} \\
\end{array}$ & $\begin{array}{l}\text { Band } \\
\text { gap } \\
(\mathrm{eV})\end{array}$ & Work and method \\
\hline 1 & $\begin{array}{l}8.345- \\
8.364\end{array}$ & $\begin{array}{l}13.0- \\
18.4\end{array}$ & $\begin{array}{c}14.59- \\
58.45\end{array}$ & $\begin{array}{l}18.56- \\
131.25\end{array}$ & $\begin{array}{l}1.74- \\
6.94\end{array}$ & & $\begin{array}{r}2.8788- \\
3.1094\end{array}$ & $\begin{array}{c}2.0278- \\
2.3877\end{array}$ & & $\begin{array}{c}\text { M.N. Akhtar et al. } \\
\mathrm{Ni}_{0.5} \mathrm{Mg}_{x} \mathrm{Zn}_{0.5-x} \mathrm{Fe}_{2} \mathrm{O}_{4} \\
\text { (sol-gel) }[1]\end{array}$ \\
\hline 2 & $\begin{array}{l}8.363- \\
8.386\end{array}$ & $\begin{array}{l}19.00- \\
28.863\end{array}$ & & & & & & & & $\begin{array}{c}\text { D.H. Bodade et al. } \\
\mathrm{Mg}_{0.7-x} \mathrm{Ni}_{x} \mathrm{Zn}_{0.3} \mathrm{Fe}_{2} \mathrm{O}_{4} \\
\text { (sol-gel auto combustion } \\
\text { method) [2] }\end{array}$ \\
\hline 3 & $\begin{array}{c}8.349- \\
8.388\end{array}$ & $\begin{array}{l}40.06- \\
42.89\end{array}$ & $\begin{array}{c}24.7- \\
57.6\end{array}$ & $\begin{array}{l}64.6- \\
107.0\end{array}$ & & $\begin{array}{l}27.03- \\
31.17\end{array}$ & $\begin{array}{l}2.141- \\
2.279\end{array}$ & $\begin{array}{l}1.275- \\
1.323\end{array}$ & - & $\begin{array}{c}\text { P. Tiwari et al. } \\
\mathrm{Mg}_{0.7-x} \mathrm{Ni}_{0.3} \mathrm{Zn}_{x} \mathrm{Fe}_{2} \mathrm{O}_{4} \\
\text { (Solution combustion } \\
\text { method) [3] }\end{array}$ \\
\hline 4 & $\begin{array}{l}8.3846- \\
8.4116\end{array}$ & $\begin{array}{c}43.58- \\
59.40\end{array}$ & $\begin{array}{c}25.30- \\
57.84\end{array}$ & $\begin{array}{l}18.69- \\
125.58\end{array}$ & $\begin{array}{c}0.99- \\
2.26\end{array}$ & & & & $\begin{array}{c}4.50- \\
5.60\end{array}$ & $\begin{array}{c}\text { R. Sharma } \\
\mathrm{Mg}_{0.5} \mathrm{Zn}_{0.5-x} \mathrm{Ni}_{x} \mathrm{Fe}_{2} \mathrm{O}_{4} \\
\text { (Co precipitation) [8] }\end{array}$ \\
\hline 5 & $\begin{array}{l}8.368- \\
8.404\end{array}$ & $\begin{array}{l}36- \\
59\end{array}$ & $\begin{array}{c}30.4- \\
43.1\end{array}$ & $\begin{array}{l}11.9- \\
65.8\end{array}$ & $\begin{array}{l}1.17- \\
1.82\end{array}$ & & & & & $\begin{array}{c}\text { Gabal et al. } \\
\mathrm{Ni}_{0.8-x} \mathrm{Zn}_{0.2} \mathrm{Mg}_{x} \mathrm{Fe}_{2} \mathrm{O}_{4} \\
\text { (sol-gel) [19] }\end{array}$ \\
\hline 6 & $\begin{array}{l}8.345- \\
8.4052\end{array}$ & $\begin{array}{l}12.9- \\
23.9\end{array}$ & $\begin{array}{l}29- \\
106\end{array}$ & $\begin{array}{l}72.45- \\
122.34\end{array}$ & & & & & & $\begin{array}{c}\text { A. Ghosh et al. } \\
\mathrm{Mg}_{0.7-x} \mathrm{Ni}_{0.3} \mathrm{Zn}_{x} \mathrm{Fe}_{2} \mathrm{O}_{4} \\
\text { (sol-gel auto combustion } \\
\text { method) [23] }\end{array}$ \\
\hline 7 & $\begin{array}{l}8.296- \\
8.376\end{array}$ & $\begin{array}{l}15.5- \\
54.0\end{array}$ & $\begin{array}{c}90.20- \\
97.20\end{array}$ & $\begin{array}{c}42.65- \\
48.36\end{array}$ & $\begin{array}{l}3.67- \\
3.95\end{array}$ & $\begin{array}{l}28.18- \\
108.50\end{array}$ & $\begin{array}{c}2.773- \\
2.937\end{array}$ & $\begin{array}{l}1.695- \\
1.948\end{array}$ & $\begin{array}{l}1.68- \\
1.79\end{array}$ & Present study \\
\hline
\end{tabular}

\section{Acknowledgements}

The author is thankful to Prof. T. Subbarao for his encouragement. The author is also thankful to Micro and Nano Characterization Facility, IISc, Bangalore for providing various characterization facilities under external user.

\section{Data availability statement}

Data will be made immediately available based on the request.

\section{Declaration of competing interest}

The authors declare that we have no conflicts of interest.

\section{References}

[1] Majid Niaz Akhtar, A. Rahman, A.B. Sulong, Muhammad Azhar Khan. Structural, Spectral, Dielectric and Magnetic Properties of $\mathrm{Ni}_{0.5} \mathrm{Mg}_{x} \mathrm{Zn}_{0.5-x} \mathrm{Fe}_{2} \mathrm{O}_{4}$ Nanosized ferrites for Microwave absorption and High Frequency Applications. Ceramics International, 2017, 43 (5), P. 4357-4365.

[2] Bobade D.H., Rathod S.M., Mane M.L. Sol-gel auto-combustion synthesis, structural and enhanced magnetic properties of Ni ${ }^{+2}$ substituted nanocrystalline Mg-Zn spinel ferrite. Physica B, 2012, 407, P. 3700-3704.

[3] Tiwari P., Verma R., et al. Effect of Zn addition on structural, magnetic properties and anti-structural modelling of magnesium-nickel nano ferrite. Material Chemistry and Physics, 2019, 229, P. 78-86.

[4] Asther Hossain A.K.M., Biswas T.S., et al. Investigation of structural and magnetic properties of polycrystalline $\mathrm{Ni}_{0.50} \mathrm{Zn}_{0.50-x} \mathrm{Mg}_{x} \mathrm{Fe}_{2} \mathrm{O}_{4}$ spinel ferrites. Material Chemistry and Physics, 2010, 120, P. 461-467.

[5] Ramesh S., Dhana Lakshmi B., et al. Effect of Mn/Co substitutions on the resistivity and dielectric properties of nickel-zinc ferrites. Ceramics International, 2016, 42 (8), P. 9591-9598.

[6] Zeng Aixiang, Yuan Jun. Study of Sol-Gel Auto-combustion Method Prepared $\mathrm{Ni}_{0.6-x} \mathrm{Zn}_{0.4} \mathrm{Mg}_{x} \mathrm{Fe}_{2} \mathrm{O}_{4}$. Advanced Materials Research, 2012, 463-464, P. 1052-1056.

[7] Tatarchuk T., Bououdina M., Judith Vijaya J., John Kennedy L. Spinel Ferrite Nanoparticles: Synthesis, Crystal Structure, Properties, and Perspective Applications. In: Fesenko O., Yatsenko L. (eds) Nanophysics, Nanomaterials, Interface Studies, and Applications. NANO 2016. Springer Proceedings in Physics, 2017195 P. 305-325. 
[8] Rohit Sharma, Prashant Thakur, Pankaj Sharma, Vineet Sharma. Ferrimagnetic $\mathrm{Ni}^{+2}$ doped Mg-Zn spinel ferrite nanoparticles for high density information Storage. Journal of Alloys and Compounds, 2017, 704, P. 7-17.

[9] Chandrababu Naidu Kadiyala, Madhuri Wuppulluri. Microwave Processed Bulk and Nano NiMg Ferrites: A Comparative Study on X-band Electromagnetic Interference Shielding Properties. Materials Chemistry and Physics, 2017, 187, P. 164-176.

[10] Xia A., Liu S., et al. Hydrothermal $\mathrm{Mg}_{1-x} \mathrm{Zn}_{x} \mathrm{Fe}_{2} \mathrm{O}_{4}$ spinel ferrites: Phase formation and mechanism of saturation magnetization. Materials Letters, 2013, 105, P. 199-201.

[11] Sasaki T., et al. Continuous synthesis of fine $\mathrm{MgFe}_{2} \mathrm{O}_{4}$ nanoparticles by supercritical hydrothermal reaction. Journal of Supercritical Fluids, 2010, 53, P. 92-94.

[12] Xiqian Zhao, Aimin Sun, et al. Effects of Mg Substitution on the Structural and Magnetic Properties of $\mathrm{Ni}_{0.2} \mathrm{Mg}_{x} \mathrm{Co}_{0.8}-{ }_{x} \mathrm{Fe}_{2} \mathrm{O}_{4} \mathrm{Nanoparticle}$ Ferrites. Journal of Superconductivity and Novel Magnetism, 2019, 32, P. 2589-2598.

[13] Cullity B.D. Elements of X-Ray diffraction. Second ed. Addison-Wesley, Reading MA, 1978.

[14] Rajinder Kumar, Hitanshu Kumar, Manoj Kumar, Ragini Raj Singh. Enhanced Saturation Magnetization in Cobalt Doped Ni-Zn Ferrite Nanoparticles. Journal of Superconductivity and Novel Magnetism, 2015, 28, P. 3557-3564.

[15] Satalkar M., Kane S.N., et al. Synthesis and soft magnetic properties of $\mathrm{Zn}_{0.8-x} \mathrm{Ni}_{x} \mathrm{Mg}_{0.1} \mathrm{Cu}_{0.1} \mathrm{Fe}_{2} \mathrm{O}_{4}(x=0.0-0.8)$ ferrites prepared by sol-gel auto-combustion method. Journal of Alloys and Compounds, 2014, 615, P. S313-S316.

[16] Tatarchuk T.R., Paliychuk N.D., et al. Effect of cobalt substitution on structural, elastic, magnetic and optical properties of zinc ferrite nanoparticles. Journal of Alloys and Compounds, 2018, 731, P. 1256-1266.

[17] Chandra Babu Naidu K., Madhuri W. Determination of activation energies from complex impedance parameters of microwave sintered NiMgZn ferrites. Mechanics, Materials Science and Engineering, 2017, 9.

[18] Muddassar Naeem, Nazar Abbas Shah, Iftikhar Hussain Gul, Asghari Maqsood. Structural, electrical and magnetic characterization of Ni-Mg Spinel ferrites. Journal of Alloys and Compounds, 2009, 487, P. 739-743.

[19] Gabal M.A., Bayoumy W.A. Effect of composition on structural and magnetic properties nanocrystalline $\mathrm{Ni}_{0.8}-\mathrm{Zn}_{0.2} \mathrm{Mg}_{x} \mathrm{Fe}_{2} \mathrm{O}_{4}$ ferrite. Polyhedron, 2010, 29, P. 2569-2573.

[20] Yoon Mi Kwon, Min-Young Lee, et al. Structural and Magnetic Properties of $\mathrm{Ni}_{0.6} \mathrm{Zn}_{0.4} \mathrm{Fe}_{2} \mathrm{O}_{4}$ Ferrite Prepared by Solid State Reaction and Sol-gel. Journal of Magnetics, 2014, 19 (1) P. 64-67.

[21] Jadhav, Swati, et al. Effect of $\mathrm{Cr}$ ions on physical properties of $\mathrm{Cu}-\mathrm{Zn}$ ferrite nano-particles. International Journal of Basic and Applied Research, 2011, 1, P. 50-53.

[22] Cullity B.D., Graham C.D. Introduction to magnetic materials, Wiley, IEEE Press, 2008.

[23] Ghosh A., Satalkar M., et al. Soft Magnetic Properties of $\mathrm{Mg}_{0.7-x} \mathrm{Ni}_{0.3} \mathrm{Zn}_{x} \mathrm{Fe}_{2} \mathrm{O}_{4}$ ferrites synthesized by sol-gel auto combustion technique without post-preparation thermal treatment. International Journal of Modern Physics: Conference Series, 2013, 22, P. 28-34. 